\title{
Manajemen Energi Penggunaan Pendingin Udara Pada Gedung Perkantoran Universitas Islam Malang
}

\author{
Ainun Zakiyah ${ }^{1}{ }^{1}$, Abraham Lomi $^{2}$, Fourry Handoko ${ }^{2}$ \\ 1 Fakultas Teknik, Universitas Islam Malang \\ 2 Teknik Elektro, ITN Malang \\ 3 Program Studi Teknik IndustriS-2, Pascasarjana, ITN Malang \\ *E-mail: zakiyah.muhammad11@gmail.com
}

\begin{abstract}
Abstrak
Pemakaian energi di gedung perkantoran didominasi oleh penggunaan AC (Air Conditioner) sebesar 53\%.Penggunaan AC (Air Conditioner) bertujuan untuk memberikan kondisi yang nyaman kepada pegawai sehingga meningkatkan kinerja pegawai.Kondisi pemasangan AC (Air Conditioner) pada gedung perkantoran belum sesuai dengan standart yang ditentukan.Oleh karena itu perlu dilakukan perencanaan pemasangan AC (Air Conditioner) yang sesuai dengan standart ruangan kerja.Berdasarkan Standart Nasional Indonesia (SNI) standart temperature udara $22^{\circ} \mathrm{C}$ $25^{\circ} \mathrm{C}$.Penelitian ini menggunakan pendekatan PDCA untuk mendapatkan efisiensi penggunaan energi. Dengan adanya pemasangan AC (Air Conditioner) otomatis akan meningkatkan penggunaan energi sehingga perlu dilakukan efisiensi penggunaan energi. Efisiensi energi dilakukan dengan pengurangan jam penggunaan AC (Air Conditioner) sehingga konsumsi energi akan berkurang.
\end{abstract}

Kata Kunci : Efisiensi, PDCA, Standart Nasional Indonesia (SNI).

\section{Pendahuluan}

Peningkatan jumlah mahasiswa berdampak pada penggunaan energi listrik yang juga semakin meningkat. Salah satu bangunan yang penggunaan energinya paling besar adalah Gedung B Unisma yang digunakan untuk ruang kantor, ruang kelas dan gedung pertemuan sebanyak 7 lantai. Meningkatnya jumlah energi yang terpakai berpengaruh terhadap biaya operasional yang dikeluarkan oleh bagian keuangan Unisma. Penggunaan energi di Gedung B Unisma paling banyak diserap oleh penggunaan AC (Air Conditioner) sebesar 53\% .

Oleh karena itu perlu dilakukan manajemen energi untuk memperbaiki efisiensi energi akibat penggunaan AC (Air Conditioner). Manajemen energi merupakan program terpadu yang direncanakan dan dilaksanakan secara sistematis untuk memanfaatkan sumber daya energi secara efektif dan efisien dengan melakukan perencanaan, pencatatan, pengawasan dan evaluasi secara kontinyu tanpa mengurangi kualitas pelayanan[1]. Secara geografis Indonesia termasuk daerah tropis tetapi secara suhu tidak semua wilayah Indonesia merupakan daerah tropis. Suhu untuk daerah tropis rata - rata $20^{\circ} \mathrm{C}$ akan tetapi sebagian wilayah Indonesia suhunya mencapai $35^{\circ} \mathrm{C}$, kondisi ini kurang menguntungkan bagi manusia untuk beraktifitas sebab produktifitas manusia cenderung turun pada kondisi udara yang tidak nyaman missal terlalu panas maupun terlalu dingin. Suhu nyaman thermal untuk orang Indonesia berada pada rentang suhu $22,8^{\circ} \mathrm{C}-25,8^{\circ} \mathrm{C}$ dengan kelembaban $70 \%$. Langkah yang paling mudah untuk mengakomodasi kenyamanan tersebut adalah dengan melakukan pengkondisian secara mekanis (penggunaan AC) di dalam bangunan yang berdampak pada bertambahnya penggunaan energi listrik[2].

Menghitung kebutuhan daya dan kapasitas AC(Air Conditioner) ruangan; Kompresor adalah sebuah alat yang berfungsi untuk menyalurkan gas refrigeran ke seluruh sistem. Ukuran dari kapasitas AC(Air Conditioner) adalah PK (paardekracth) yang artinya tenaga kuda. Satu PK sama artinya 
dengan 735.5 watt/jam sama artinya dengan 0,986 $\mathrm{hp}$ [3]. Berikut adalah rumus perhitungan kebutuhan AC (Air Conditioner) dalam ruangan:

$$
\text { Kebutuhan } A C\left(\frac{B T U}{h}\right)=L x W x 500 B T U / h
$$

Tabel 1. Teknis Konservasi Energi Pada Bangunan Gedung

\begin{tabular}{|c|c|c|}
\hline \multicolumn{3}{|c|}{$\begin{array}{l}\text { Suhu nyaman menurut standart tata cara perencanaan Teknis Konservasi Energi Pada } \\
\text { Bangunan Gedung }\end{array}$} \\
\hline & $\begin{array}{l}\text { Temperatur Efektif } \\
\text { (TE) }\end{array}$ & Kelembaman (RH) \\
\hline 1. Sejuk Nyaman & $20,5^{\circ} \mathrm{C}-22,8^{\circ} \mathrm{C}$ & $50 \%$ \\
\hline Ambang Atas & $24^{\circ} \mathrm{C}$ & $80 \%$ \\
\hline 2. Nyaman Optimal & $22,8^{\circ} \mathrm{C}-25,8^{\circ} \mathrm{C}$ & $70 \%$ \\
\hline Ambang Atas & $28^{\circ} \mathrm{C}$ & \\
\hline 3. Hangat Nyaman & $25,8^{\circ} \mathrm{C}-27,1^{\circ} \mathrm{C}$ & $60 \%$ \\
\hline Ambang Atas & $31^{\circ} \mathrm{C}$ & \\
\hline
\end{tabular}

\section{Metodologi Penelitian}

Besarnya tingkat konsumsi energi listrik di Unisma berpengaruh terhadap biaya bulanan yang dikeluarkan sehingga perlu dilakukan analisa efisiensi penggunaan energi listrik. Salah satu cara yang bisa ditempuh dengan pendekatan Continuous Improvement yang biasa disebut PDCA (Plan, Do, Check,Action) yang dikenal dengan sebutan siklus deming [4]. Langkah - langkah dalam siklus PDCA pada sistem manajemen energi adalah:

\begin{tabular}{|c|c|}
\hline Plan (Perencanaan) & Do (Pengerjaan) \\
\hline $\begin{array}{l}\text { Menetapkan target penyimpanan energi, } \\
\text { menentukan strategi, mengidentifikasi ukuran dan } \\
\text { tanggungjawab menyediakan sumber daya yang } \\
\text { penting, menyiapkan rencana untuk mendorong } \\
\text { keterlibatan karyawan dan membutuhkan } \\
\text { kemampuan team work yang baik agar dapat } \\
\text { mengukur dan memastikan konsumsi energi yang } \\
\text { minimum dalam aktivitas yang dilakukan. }\end{array}$ & $\begin{array}{l}\text { Menetapkan struktur manajemen untuk } \\
\text { memelihara proses yang berkelanjutan, } \\
\text { melakukan peningkatan nilai efisiensi teknologi } \\
\text { dan prosedur sehingga diperoleh implementasi } \\
\text { perubahan. }\end{array}$ \\
\hline $\begin{array}{l}\text { Action (Tindakan) } \\
\text { Jika perubahan dianggap suskes maka } \\
\text { implementasi perubahan tersebut dalam skala } \\
\text { yang lebih besar dan dipertahankan hasilnya. } \\
\text { Optimasi strategi melalui konsolidasi pada data } \\
\text { energi dan informasi baru. Evaluasi progress dan } \\
\text { penentuan tujuan baru. }\end{array}$ & $\begin{array}{l}\text { Check (Pemeriksaan) } \\
\text { Melihat kembali tingkat pencapaian target dan } \\
\text { efektifitas dari sistem manajemen energi dan } \\
\text { mengumpulkan ide - ide dengan menggunakan } \\
\text { data untuk menganalisa apakah perubahan yang } \\
\text { dilakukan telah atau akan menghasilkan } \\
\text { perbedaan yang berarti. }\end{array}$ \\
\hline
\end{tabular}

\section{Hasil Penelitian}

Berdasarkan siklus PDCA pada sistem manajemen energi maka dilakukan langkah - langkah berikut: Plan (Perencanaan) Melakukan perhitungan kebutuhan AC (Air Conditioner) sesuai standart tiap ruangan dan mengetahui jumlah daya yang terpakai. Dimana dilakukan perbandingan kondisi eksisting beberapa ruangan belum terpasang AC (Air Conditioner), kemudian kondisi design dengan pemasangan AC (Air Conditioner) sesuai standart ruangan.

Perhitungan $\mathrm{AC}=\mathrm{P}$ X L x $500 \mathrm{BTU} / \mathrm{hr}$ 
Tabel 2. Kebutuhan AC (Air Conditioner)(BTU/hr)

\begin{tabular}{|c|c|}
\hline \multicolumn{2}{|c|}{ Konversi sistem daya AC } \\
\hline PK & BTU/hr \\
\hline 0,5 & 5000 \\
\hline 0,75 & 7000 \\
\hline 1 & 9000 \\
\hline 1,5 & 12000 \\
\hline 2 & 18000 \\
\hline 2,5 & 24000 \\
\hline
\end{tabular}

Tabel 3. Jumlah AC (Air Conditioner)Terpasang

\begin{tabular}{|c|c|c|c|c|c|}
\hline No & Ruangan & Eksisting & Design & Daya (Watt) & Kwh Total \\
\hline 1 & R. FAI & 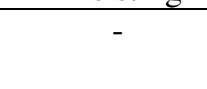 & AC Terpasang & 5520 & $\begin{array}{l}1148,1 \\
6\end{array}$ \\
\hline 2 & R. FT & - & $1 \frac{1}{2} \mathrm{PK}, 5$ buah & 5520 & $\begin{array}{l}1148,1 \\
6\end{array}$ \\
\hline 3 & R. FIA & - & $1 \frac{1}{2} \mathrm{PK}, 5$ buah & 5520 & $\begin{array}{l}1148,1 \\
6\end{array}$ \\
\hline 4 & R. Faperta & - & $1 \frac{1}{2} \mathrm{PK}, 5$ buah & 5520 & $\begin{array}{l}1148,1 \\
6\end{array}$ \\
\hline 5 & R. FMIPA & 1 PK, 1 Buah & $1 \frac{1}{2} \mathrm{PK}, 5$ buah & 2208 & 459,26 \\
\hline 6 & R. FKIP & 1 PK, 1 Buah & $1 \frac{1}{2} \mathrm{PK}, 2$ buah & 2208 & 459,26 \\
\hline 7 & F.Hukum & 1 PK, 1 Buah & $1 \frac{1}{2} \mathrm{PK}, 2$ buah & 2208 & 459,26 \\
\hline 8 & R. Fapet & 1 PK, 1 Buah & $1 \frac{1}{2} \mathrm{PK}, 2$ buah & 2208 & 459,26 \\
\hline 9 & $\begin{array}{l}\text { R. Japan } \\
\text { Corner }\end{array}$ & 1 PK, 1 Buah & $1 \frac{1}{2} \mathrm{PK}, 2$ buah & 2208 & 459,26 \\
\hline 10 & R. Mini Store & $1 \mathrm{PK}, 1 \mathrm{Buah}$ & $1 \frac{1}{2} \mathrm{PK}, 2$ buah & 1472 & 306,18 \\
\hline 11 & $\begin{array}{ll}\text { R. } & \text { Book } \\
\text { Store } & \end{array}$ & 1 PK, 1 Buah & 2PK, 1 buah & 1472 & 306,18 \\
\hline 12 & $\begin{array}{l}\text { R. Koperasi } \\
\text { Iqtisod }\end{array}$ & 1 PK, 1 Buah & 2PK, 1 buah & 1472 & 306,18 \\
\hline 13 & R. Percetakan & - & $2 \mathrm{PK}, 1$ buah & 1472 & 306,18 \\
\hline \multicolumn{3}{|c|}{ TOTAL } & & 39008 & $\begin{array}{l}8113,6 \\
6\end{array}$ \\
\hline
\end{tabular}

Besar pengeluaran per bulan untuk pemakaian AC (Air Conditioner) $=8113,66 \mathrm{kwh} \times \mathrm{Rp} \mathrm{900/ \textrm {kwh } =}$ Rp 7.302.294. Do (Pengerjaan) konsumsi energi dari pemakaian AC (Air Conditioner)cukup tinggi sehingga perlu dilakukan efisiensi penggunaan AC (Air Conditioner)dengan mengurangi penggunaan AC (Air Conditioner) pada jam tertentu, dan mematikan AC (Air Conditioner)pada saat jam istirahat.Berikut kondisi konsumsi energi setelah dilakukan pengurangan jam pemakaian AC (Air Conditioner).

Tabel 4. Konsumsi Energi dari AC (Air Conditioner)

Setelah Dilakukan Pengurangan Jam Pemakaian

\begin{tabular}{|c|l|c|c|c|}
\hline No & \multicolumn{1}{|c|}{ Ruangan } & Design & Daya (Watt) & Jumlah Kwh \\
\hline 1 & R. FAI & AC Terpasang & 5520 & 574,08 \\
\hline 2 & R. FT & $1 \frac{1}{2}$ PK, 5 buah & 5520 & 574,08 \\
\hline 3 & R. FIA & $1 \frac{1}{2}$ PK, 5 buah & 5520 & 574,08 \\
\hline 4 & R. Faperta & $1 \frac{1}{2}$ PK, 5 buah & 5520 & 574,08 \\
\hline
\end{tabular}


Jurnal Teknologi dan Manajemen Industri, Vol. 4 No. 2, Agustus 2018 Pascasarjana Institut Teknologi Nasional Malang

\begin{tabular}{|c|c|c|c|c|}
\hline 5 & R. FMIPA & $1 \frac{1}{2} \mathrm{PK}, 5$ buah & 2208 & 229,63 \\
\hline 6 & R. FKIP & $1 \frac{1}{2} \mathrm{PK}, 2$ buah & 2208 & 229,63 \\
\hline 7 & F.Hukum & $1 \frac{1}{2} \mathrm{PK}, 2$ buah & 2208 & 229,63 \\
\hline 8 & R. Fapet & $1 \frac{1}{2} \mathrm{PK}, 2$ buah & 2208 & 229,63 \\
\hline 9 & $\begin{array}{l}\text { R. Japan } \\
\text { Corner }\end{array}$ & $1 \frac{1}{2} \mathrm{PK}, 2$ buah & 2208 & 229,63 \\
\hline 10 & R. Mini Store & $1 \frac{1}{2} \mathrm{PK}, 2$ buah & 1472 & 153,09 \\
\hline 11 & $\begin{array}{ll}\text { R. } & \text { Book } \\
\text { Store } & \\
\end{array}$ & $2 \mathrm{PK}, 1$ buah & 1472 & 153,09 \\
\hline 12 & $\begin{array}{l}\text { R. Koperasi } \\
\text { Iqtisod }\end{array}$ & $2 \mathrm{PK}, 1$ buah & 1472 & 153,09 \\
\hline 13 & R. Percetakan & 2PK, 1 buah & 1472 & 153,09 \\
\hline \multicolumn{3}{|c|}{ TOTAL } & 39008 & 4056,83 \\
\hline
\end{tabular}

Setelah dilakukan manajemen energi melalui pengurangan jam penggunaan AC (Air Conditioner)maka biaya pengeluaran bulanan berkurang.

Biaya pengeluaran listrik $=4056,83 \mathrm{kwh} \times \mathrm{Rp} 900 / \mathrm{kwh}=\mathrm{Rp} .3 .651 .147$

Setelah dilakukan pengurangan jam penggunaan AC (Air Conditioner)maka diperoleh efisiensi sebesar:

Efisiensi $=8113,66-4056,83 \times 100 \%=50 \%$

Check (Pemeriksaan) Melakukan check list untuk mengontrol penggunaan AC (Air Conditioner) seminimal mungkin di masing - masing ruangan dibawah tanggungjawab Kepala Tata Usaha.

Action (Tindakan) Setelah melalui tahapan plan, do, dan check maka untuk mendapatkan efisiensi pemakaian energi listrik dari sektor AC (Air Conditioner)bisa dilakukan beberapa langkah berikut ini:

1. Menggunakan AC (Air Conditioner)inverter low watt.

2. Memasang $\mathrm{AC}$ (Air Conditioner)sesuai dengan kapasitas ruangan.

3. Melakukan pelatihan tentang pentingnya hemat energi.

4. Mengeluarkan SOP pemakaian peralatan listrik.

5. Memberikan penghargaan kepada pegawai yang bisa meminimalkan konsumsi energi dalam menjalankan kinerjanya selama kurun waktu tertentu.

\section{Kesimpulan}

Besarnya konsumsi energi dari pemakaian AC (Air Conditioner)pada gedung B Unisma diakibatkan kurangnya kesadaran pegawai untuk peduli terhadap pemakaian AC (Air Conditioner), dan kurangnya kontrol dari petugas piket pada masing - masing ruangan untuk mengecek kondisi AC (Air Conditioner)pada saat jam pulang kerja. Untuk itu perlu dilakukan kegiatan kampanye hemat energi dilingkungan Unisma untuk menumbuhkan kesadaran pegawai tentang pentingnya efisiensi pemakaian energi, sehingga target efisiensi yang ingin dicapai akan terwujud. Dengan terwujudnya efisiensi energi maka akan menurunkan biaya dari sisi penggunaan energi listrik, sehingga biaya yang ada bisa dialokasikan untuk kepentingan lain yang lebih urgent.

\section{Daftar Referensi}

[1] I Wayan Swi Putra, 2015. Studi Terhadap Konservasi Energi Pada Gedung Sewaka Darma Kota Denpasar Yang Menerapkan Konsep Green Building, Jurnal Universitas Udayana.

[2] Basaria Tolorosa, 2005. Menciptakan Kenyamanan Thermal Dalam Bangunan, Jurnal Sistem Teknik Industri. Universitas Sumatra Utara. 
Jurnal Teknologi dan Manajemen Industri, Vol. 4 No. 2, Agustus 2018

Pascasarjana Institut Teknologi Nasional Malang

[3] Najamudin, 2014. Cara Menghitung Kebutuhan Daya dan Kapasitas AC (Air Conditioning) Berdasarkan Volume Ruang yang Akan Digunakan, Jurnal Teknik Mesin. Universitas Bandar Lampung, Lampung.

[4] Kahleborn, Walter, Kabisch, Sibylle, Kleim, Johanna, Ritcher, Ina, Schurman, Silas, DIN EN 16001, 2010. Energy Management Systems In Practice, BMU. Berlin. 